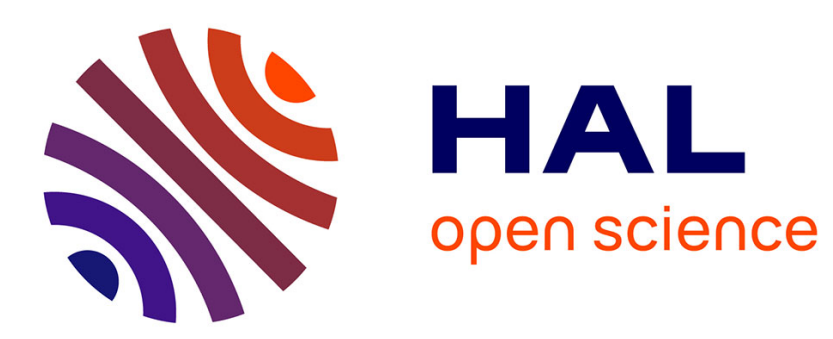

\title{
First record of hawker dragonflies from Eocene Baltic amber (Odonata: Anisoptera: Gomphaeschnidae)
}

\author{
Stefan Pinkert, Günter Bechly, André Nel
}

\section{To cite this version:}

Stefan Pinkert, Günter Bechly, André Nel. First record of hawker dragonflies from Eocene Baltic amber (Odonata: Anisoptera: Gomphaeschnidae). Zootaxa, 2017, 4272 (2), pp.263-275. 10.11646/zootaxa.4272.2.7 . hal-01547445

\section{HAL Id: hal-01547445 \\ https://hal.sorbonne-universite.fr/hal-01547445}

Submitted on 4 Jul 2017

HAL is a multi-disciplinary open access archive for the deposit and dissemination of scientific research documents, whether they are published or not. The documents may come from teaching and research institutions in France or abroad, or from public or private research centers.
L'archive ouverte pluridisciplinaire HAL, est destinée au dépôt et à la diffusion de documents scientifiques de niveau recherche, publiés ou non, émanant des établissements d'enseignement et de recherche français ou étrangers, des laboratoires publics ou privés. 
First record of hawker dragonflies from Eocene Baltic amber (Odonata: Anisoptera:

\title{
Gomphaeschnidae)
}

\section{Stefan Pinkert ${ }^{1}$, Günter Bechly ${ }^{2,4} \&$ André Nel $^{3,4}$}

\section{Affiliations}

${ }^{1}$ Faculty of Biology, Department of Ecology-Animal Ecology, Philipps-Universität

Marburg, Karl-von-Frisch-Strasse 8, 35043 Marburg, Germany. E-mail:

StefanPinkert@posteo.de

${ }^{2}$ Am Stadtgarten 4, 71032 Böblingen, Germany.E-mail: bechly@mac.com

${ }^{3}$ Institut de Systématique, Évolution, Biodiversité, ISYEB - UMR $7205-C N R S$, MNHN, UPMC, EPHE, Muséum national d'Histoire naturelle, Sorbonne Universités, 57 rue Cuvier, CP 50, Entomologie, F-75005, Paris, France.E-mail: anel@mnhn.fr

${ }^{4}$ Corresponding authors.

\begin{abstract}
Based on three specimens the first record of hawker dragonflies from Baltic amber is described in a new genus with two new species: Elektrogomphaeschna peterthieli gen. et sp. nov. and E. annekeae sp. nov.. They belong to the family Gomphaeschnidae and are tentatively attributed to the extinct subfamily Gomphaeschnaoidinae. The latter was previously only known from Cretaceous fossils and is here shown to have survived the $\mathrm{K}-\mathrm{Pg}$ mass extinction event. This discovery also confirms the still higher diversity of Gomphaeschnidae during the Paleogene compared to the Neogene that was dominated by the more derived Aeshnidae sensu stricto.
\end{abstract}


Keywords: Odonata, Gomphaeschnidae, Gomphaeschnaoidinae, Eocene, Baltic amber, gen. et sp. nov.

\section{Introduction}

Baltic amber is a fossil resin from a conifer tree species (most probably Sciadopithys or Pseudolarix, Wolfe et al., 2009) that formed widespread tropical/subtropical forests from Scandinavia to Eastern Europe during the Middle and Upper Eocene. Most amber pieces originate from secondary deposits along the coast of the Baltic Sea. While small insects (predominantly Diptera and Hymenoptera) are abundant and completely preserved as inclusions in Baltic amber, large insects are much rarer and usually fragmentary, because they could either escape the sticky resin or where eaten by scavenging insects before completely embedded. Odonata are especially rare in Baltic amber (Bechly 1996a, 1998), while they are very diverse and surprisingly frequent in Mid-Cretaceous Burmese amber (Zheng et al. 2016a,b, 2017, etc.). Anisoptera are even more elusive, with only four specimens yet been reported from Baltic amber (Bechly 1998; Bechly \& Wichard 2008), and only one more from Paris Basin amber (Fleck et al. 2000), and three more from Burmese amber (Schädel \& Bechly 2016; Zheng et al. 2016, 2017). Schädel \& Bechly (2016) already briefly mentioned one undescribed Macromiidae and two undescribed specimens (described herein) of Gomphaeschninae in the Baltic amber collection of SMNS. Based on totally three specimens of two new species of the same new genus we here describe the first record of hawker dragonflies in Baltic amber and only the third record of this Anisopteran group in amber at all (Zheng et al. 2016b, 2017).

\section{Material and methods}


The holotype SMNS BB-2390 and paratype SMNS BB-2825 specimens of Elektrogomphaeschna peterthieli gen. et sp. nov. were acquired by SMNS from German private collectors. They were examined with a Leica M80 (1.6 Plan Achromat lens) stereoscopic microscope, and photographed with a Leica DFC490 digital macroscopic photo system working on a Leica Z16-Apo macroscope with Leica Application Suite 3.8.0. Photographs were stacked with Helicon Focus 6.7.1 pro and stitched with Panorama Stitcher 1.8 on a MacBook Pro. Line drawings were made with Adobe Photoshop CS5 from the photographs.

The holotype specimen of Elektrogomphaeschna annekeae sp. nov. (MNHN.F.A58663) was acquired from a local market in Poland, unfortunately without further information on the original locality where it was found. It was examined with a Nikon SMZ1500 dissecting microscope and illustrated with the aid of a drawing tube attached to the microscope. Line drawings were made using Adobe Photoshop CS6 and Inkscape graphic software.

The wing venation nomenclature used in this paper follows Riek \& Kukalová-Peck (1984), as amended by Nel et al. (1993) and Bechly (1996b). We use the following standard abbreviations: AA anal vein, AP anal posterior, Ax0 Ax1 Ax2 primary antenodal crossveins, $\mathrm{ScP}$ subcostal posterior vein, $\mathrm{CuAa}$ distal branch of cubitus anterior, $\mathrm{CuAb}$ proximal branch of cubitus anterior, T discoidal triangle, h hypertriangle, IR1, IR2 intercalary radial veins, MAa distal branch of media anterior, MAb posterior branch of median anterior (distal side of triangle), MP media posterior, N nodus, 'O' lestine oblique vein, $\mathrm{Pt}$ pterostigma, RA radius anterior and RP radius posterior. We follow the classification of Bechly et al. (2001) and Ellenrieder (2002a) to compare our fossil to other known Aeshnoptera.

\section{Systematic Paleontology}


Order Odonata Fabricius, 1793

Clade Aeshnoptera Bechly, 1996

Family Gomphaeschnidae Tillyard \& Fraser, 1940

Subfamily Gomphaeschnaoidinae Bechly et al., 2001

Genus Elektrogomphaeschna gen. nov.

Type species. Elektrogomphaeschna peterthieli sp. nov.

Other species. Elektrogomphaeschna annekeae sp. nov.

Etymology. Named after Elektron, Greek name for amber, and the extant dragonfly genus Gomphaeschna. Gender feminine.

Diagnosis. Ax2 not far distal of arculus; only a single secondary antenodal between Ax1 and Ax2 in the forewing and two in the hind wing; triangles elongate and two-celled in both wings; hypertriangles and subtriangles free; pterostigmata short (spanning 2-3 cells), basal and distal sides not parallel, with very oblique but straight brace bein; RP1 and RP2 basally not parallel but weakly divergent; a long and straight vein IR1 with only one row of cells between it and RP1; RP2 and IR2 smoothly curved and smoothly diverging, not undulating and abruptly diverging; RP3/4 and MA not undulate; 3-4 cells between apex of discoidal triangle and base of Mspl; one row of cells between Mspl and MAa and between Rspl and IR2.

Comment. Attribution of the two holotypes of the two new species to the same genus is based on the great general similarity in their wing venation and especially the very unique derived character states of IR1 and RP2.

\section{Elektrogomphaeschna peterthieli sp. nov.}

(Figs. 1-4) 
Material. Holotype SMNS BB-2390 and paratype SMNS BB-2825, stored in the collection of the state Museum of Natural History Stuttgart in Germany.

Etymology. Named in honour of Mr. Peter Thiel (San Francisco, USA) for his generous support of the research of the second author.

Age and outcrop. Eocene (most probably Middle-Upper Eocene, Lutetian to Bartonian or Priabonian, Standke, 2008), Baltic amber.

Diagnosis. Distinguished from the only other species E. annekeae sp. nov. by the distinctly smaller size (forewing length only $27-31 \mathrm{~mm}$ instead of about $43 \mathrm{~mm}$ ), correlated with smaller number of postnodal crossveins (12 instead of 15); Ax2 in more basal position at level of basal of triangle or even somewhat basal of triangle (instead of level of middle of triangle); origin of Mspl separated by four cells (instead of three cells) from distal angle of triangle. Description. Holotype SMNS BB-2390 (figs. 1-2): An isolated right pair of wings, with a complete forewing and the distal half of the hind wing. Forewing hyaline, $27.3 \mathrm{~mm}$ long; 6.6 mm max width; from arculus to nodus $8.3 \mathrm{~mm}$; from nodus to pterostigma $11.7 \mathrm{~mm}$. Pterostigma short $1.6 \mathrm{~mm}$ long and $0.5 \mathrm{~mm}$ wide), covering two cells, and strongly braced by a very oblique (but straight) crossvein that is aligned with its basal side. Twelve postnodal crossveins between nodus and pterostigma, not aligned with the corresponding postsubnodal crossveins between RA and RP1. Primary antenodal Ax1 $1.8 \mathrm{~mm}$ basal of arculus, and primary antenodal Ax2 only $0.9 \mathrm{~mm}$ distal of arculus on the level of ventral angle of triangle; a single non-aligned secondary antenodal between Ax1 and Ax2; six non-aligned secondary antenodal crossveins between $\mathrm{Ax} 2$ and nodus. ScP fusing with costal margin at nodus, of normal Anisoptera-type. Antesubnodal area hardly visible. Discoidal triangle two-celled, very elongated with a slightly bent distal side MAb; length of anterior side $2.6 \mathrm{~mm}$; of basal side $1.0 \mathrm{~mm}$; of distal side MAb $2.5 \mathrm{~mm}$. Hypertriangle poorly visible (because of restricted viewing angle), but apparently free and $3.2 \mathrm{~mm}$ long. Several antefurcal crossveins between 
RP and MA basal of midfork (3 visible). Two bridge-crossveins basal of subnodus. Base of RP2 aligned with subnodus. Only a single oblique vein ' $\mathrm{O}$ ', one cell distal of subnodus. A long and nearly straight Rspl, parallel to IR2 with only a single row of cells between it and IR2; two convex secondary veins visible in area between Rspl and RP3/4. IR2 only gently curved. RP2 and IR2 begin to diverge somewhat basal of pterostigma with 2-3 rows of cells in widened area between these two veins. RP2 weakly curved but not undulated. RP2 and RP1 only slightly diverging basally with only a single row of cells in area in-between, but 2.5 cells basal of pterostigma they become divergent with two or more rows of cells. Well-defined long and nearly straight IR1 closely parallel to RP1 with only a single row of cells in-between. RP3/4 and MA parallel and gently curved with only a single row of cells in-between, except for a short area with two rows of cells near posterior margin of wing. Mspl long, straight, and parallel to MA with a single row of cells in-between. Postdiscoidal area basally with two rows of cells, but distally strongly widened (width near discoidal triangle $1.1 \mathrm{~mm}$ ). MP ending distal of nodus. Cubital area not preserved.

Hind wing hyaline, base half missing; preserved part $17.9 \mathrm{~mm}$ long; $6.7 \mathrm{~mm}$ max width near nodus. Pterostigma short (1.6 mm long and $0.6 \mathrm{~mm}$ wide), covering three cells, and strongly braced by a very oblique (but straight) crossvein that is aligned with its basal side. Ten postnodal crossveins between nodus and pterostigma, poorly aligned with the corresponding postsubnodal crossveins between RA and RP1. Base of RP2 aligned with subnodus. Only a single oblique vein 'O', less than one cell distal of subnodus. A long and slighly bulged Rspl, parallel to IR2 with only a single row of cells between it and IR2; two convex secondary veins visible in area between Rspl and RP3/4. IR2 only gently curved. RP2 and IR2 begin to diverge somewhat basal of pterostigma with 2-3 rows of cells in widened area between these two veins. RP2 weakly curved but not undulated. RP2 and RP1 only slightly diverging basally with only a single row of cells in area in-between, but 5 cells basal 
of pterostigma they become divergent with two or more rows of cells. Well-defined long and nearly straight IR1 closely parallel to RP1 with only a single row of cells in-between. RP3/4 and MA parallel and gently curved with only a single row of cells in-between, except for a short area with two rows of cells near posterior margin of wing. Mspl long, straight, and parallel to MA with a single row of cells in-between. Part of median area and all of cubital area not preserved.

Paratype SMNS BB-2825 (figs. 3-4): An incompletely preserved left pair of wings. Forewing with basal half mostly preserved, but of the distal half only a part of the postnodal and postsubnodal area is preserved. Wing hyaline, preserved part $23.3 \mathrm{~mm}$ long (estimated total length about $31 \mathrm{~mm}$ ); from arculus to nodus $9.4 \mathrm{~mm}$. Pterostigma not preserved. Nine postnodal crossveins preserved, not aligned with the corresponding postsubnodal crossveins. Primary antenodal Ax1 $2.0 \mathrm{~mm}$ basal of arculus, and primary antenodal Ax2 only $0.5 \mathrm{~mm}$ distal of arculus and even slightly basal of triangle; a single non-aligned secondary antenodal between Ax1 and Ax2; eight non-aligned secondary antenodal crossveins between Ax2 and nodus. ScP fusing with costal margin at nodus, of normal Anisoptera-type. Antesubnodal area with 8 crossveins and a short gap directly basal of subnodus. Discoidal triangle two-celled, very elongated with a slightly bent distal side MAb; length of anterior side $2.9 \mathrm{~mm}$; of basal side about $1.0 \mathrm{~mm}$; of distal side MAb about $2.5 \mathrm{~mm}$. Hypertriangle free $(3.5 \mathrm{~mm}$ long, max. $0.4 \mathrm{~mm}$ wide). Subdiscoidal cell free; subdiscoidal vein not ending at basal angle of triangle. Five antefurcal crossveins between RP and MA basal of midfork. Base of RP2 aligned with subnodus. RP3/4 and MA parallel and gently curved with only a single row of cells inbetween. Mspl long, straight, and parallel to MA with a single row of cells in-between. Postdiscoidal area basally with two rows of cells, but distally strongly widened (width near discoidal triangle $1.6 \mathrm{~mm}$ ). MP ending distal of nodus. Cubital area not preserved. 
Hind wing with only an antero-basal fragment preserved. Wing hyaline. Primary antenodal Ax1 $2.0 \mathrm{~mm}$ basal of arculus, and primary antenodal Ax2 $1.8 \mathrm{~mm}$ distal of arculus on the level of middle of triangle; two non-aligned secondary antenodals between Ax1 and Ax2; eight non-aligned secondary antenodal crossveins between Ax2 and nodus. ScP fusing with costal margin at nodus, of normal Anisoptera-type. Antesubnodal area with several crossveins (five preserved). Discoidal triangle two-celled and elongated; length of anterior side $2.9 \mathrm{~mm}$, of basal side $1.1 \mathrm{~mm}$, of distal side MAb about $2.7 \mathrm{~mm}$. Hypertriangle free $(3.2$ $\mathrm{mm}$ long, precise width cannot be determined because of viewing angle). Subdiscoidal cell free; subdiscoidal vein not ending at basal angle of triangle. Five antefurcal crossveins between RP and MA basal of midfork.

Comment. Attribution of the paratype specimen to the same species as the holotype is based on the nearly identical wing venation in the preserved parts of both specimens and the only insignificant difference in size.

\section{Elektrogomphaeschna annekeae sp. nov.}

(Figs. 5-8)

Material. Holotype MNHN.F.A58663, stored in the collection of the Muséum National d'Histoire Naturelle in Paris, France.

Etymology. Named after the wife of first author, Anneke.

Age and outcrop. Eocene (most probably Upper Eocene, Bartonian or Priabonian), Baltic amber.

Diagnosis. Distinguished from the type species by the distinctly larger size (forewing length about $43 \mathrm{~mm}$ instead of only $27-31 \mathrm{~mm}$ ), correlated with larger number of postnodal crossveins (15 instead of 12); Ax2 in more distal position at level of middle of triangle 
(instead of level of basal angle of triangle or even slightly basal of triangle); origin of Mspl separated by three cells (instead of four cells) from distal angle of triangle.

Description. Two forewings with bases missing, fossilized with an ant, a fly and a curculionid beetle as syninclusions. Forewing hyaline, preserved part $36.0 \mathrm{~mm}$ long (estimated total length about $43 \mathrm{~mm}$ ); $7.3 \mathrm{~mm}$ wide; from arculus to nodus about $13.0 \mathrm{~mm}$; from nodus to pterostigma $18.5 \mathrm{~mm}$. Pterostigma $2.5 \mathrm{~mm}$ long and $0.8 \mathrm{~mm}$ wide, covering three cells, and strongly braced by a very oblique (but straight) crossvein that is aligned with its basal side. Fifteen postnodal crossveins between nodus and pterostigma, not aligned with thirteen corresponding postsubnodal crossveins between RA and RP1. Vein Ax2 in basal position on the level of the ventral side of the triangle, stronger than six secondary antenodal crossveins between costal margin and $\mathrm{ScP}$ that are not aligned with those of second row between ScP and RA. ScP fusing with costal margin at nodus, of normal Anisoptera-type. Six antesubnodal crossveins visible in median part of area between RA and RP basal of subnodus with an incomplete distal gap (with two crossveins) immediately basal of subnodus. Discoidal triangle probably two-celled, very elongated with a slightly bent distal side MAb; length of anterior side probably $4.3 \mathrm{~mm}$; of basal side probably $2.0 \mathrm{~mm}$; of distal side MAb $4.1 \mathrm{~mm}$. Hypertriangle triangular, free of crossveins in preserved part, and rather narrow (length about $5.5 \mathrm{~mm}$; max. width $0.5 \mathrm{~mm}$ ). Basal area between RP and MA probably traversed by numerous antefurcal crossveins (four are preserved). Two bridge-crossveins basal of subnodus. Base of RP2 aligned with subnodus. Only a single oblique vein 'O', one cell distal of subnodus. A long and nearly straight Rspl, parallel to IR 2 with only a single row of cells between it and IR2; at least one convex secondary vein visible in area between Rspl and RP3/4. IR2 nearly straight. RP2 and IR2 begin to diverge somewhat basal of pterostigma with three rows of cells in widened area between these two veins. RP2 weakly curved but not undulated. RP2 and RP1 basally only slightly diverging with a single row of cells in-between, 
but four cells basal of pterostigma they become more strongly divergent with two or more rows of cells and a well-defined long and nearly straight IR1 in-between. RP3/4 and MA parallel and gently curved with only a single row of cells in-between, except for a short area with two rows of cells near posterior margin of wing. Mspl long and parallel to MA with a single row of cells between it and MA. Postdiscoidal area distally strongly widened (width near discoidal triangle $2.1 \mathrm{~mm}$; width at wing margin $4.8 \mathrm{~mm}$ ); two rows of cells in postdiscoidal area immediately distal of discoidal triangle; MP ending distal of nodus. Cubital area hardly preserved.

Discussion. The narrow area between RP1 and RP2, the long and well-defined Rspl and Mspl, plus the elongate shape of discoidal triangle with a distinct angle in MAb, MP and CuA closely parallel with only one row of cells between them up to the wing margin, distal accessory oblique vein between RP2 and IR2 absent, basal lestine oblique vein shifted basally, distal primary antenodal bracket ax 2 is shifted distinctly basal of level of distal angle of discoidal triangle, and two rows of cells in basal part of postdiscoidal area are characters that allow an attribution of Elektrogomphaeschna gen. nov. to the clade Neoaeshnida Bechly, 1996 (= Aeshnidae sensu Dijkstra et al. 2013) within Aeshnoptera (Bechly 2016).

Within this clade, the new genus lacks the apomorphic characters states (e.g., forked IR2) of the more derived families like Allopetaliidae, Brachytronidae, Telephlebiidae, and Aeshnidae, but shares several putative synapomorphies with the most basal family Gomphaeschnidae, viz. most distal part of antesubnodal area between RA and RP free of antesubnodal crossveins, no accessory cubito-anal crossveins in the submedian space between CuP-crossing and PsA, discoidal triangles only divided into two cells by a single crossvein, and hypertriangles secondarily unicellular. 
Within Gomphaeschnidae the recent subfamily Gomphaeschninae Tillyard \& Fraser, 1940 lacks apomorphic wing venational characters that would allow a positive attribution of the new genus to this subfamily. The Gomphaeschninae currently comprise the four modern genera Gomphaeschna Selys, 1871, Sarasaeschna Karube \& Yeh, 2001, Oligaeschna Selys, 1889, and Linaeschna Martin, 1909, plus five fossil genera (viz. Alloaeschna Wighton \& Wilson, 1986, Cretalloaeschna Jarzembowski \& Nel, 1996, Sophoaeschna Zhang et al., 2008, Falsisophoaeschna Zhang et al., 2008, and Anglogomphaeschna Nel \& Fleck, 2014). It must be noted that the Recent genera Sarasaeschna, Oligoaeschna, and Linaeschna as well as the fossil genera Alloaeschna and Anglogomphaeschna do not share the above mentioned synapomorphic character states of Gomphaeschnidae, and thus obviously belong in a more basal position outside of Gomphaeschninae if they belong to this family at all.

Elektrogomphaeschna gen. nov. differs from all these genera in the following characters: basal and distal sides of forewing pterostigma not parallel (unknown in Anglogomphaeschna); a long and straight vein IR1 with only one row of cells between it and RP1 (Anglogomphaeschna has two rows of cells between RP1 and RP2 basal of pterostigma, but it is unclear if it is an IR1); RP2 not undulate at all but regularly curved (unknown in Anglogomphaeschna); and RP3/4 and MA not undulate (Martin 1908; Wighton \& Wilson 1986; Karube \& Yeh 2001; Ellenrieder 2002b). Even if Anglogomphaeschna should share the IR1 character, its IR1 would be much longer. Furthermore, Elektrogomphaeschna gen. nov. differs greatly from the other known characters of Anglogomphaeschna, i.e. in the much lower number of secondary antenodals betwen Ax1 and Ax2 (only 1-2 instead of four in Anglogomphaeschna) and distal of Ax2 (only about eight instead of 15 in forewing of Anglogomphaeschna), the free hypertriangles (instead of hypertriangles divided by 1-3 crossveins in Anglogomphaeschna), the only two-celled triangles (instead of 3-5 celled in Anglogompaeschna), the shorter distance between apex of discoidal triangle and base of Mspl 
(only three cells instead eight cells in Anglogomphaeschna), and presence of one row of cells between Mspl and MAa, instead of at least two rows in Anglogomphaeschna (Nel \& Fleck 2014).

Even though Elektrogomphaeschna gen. nov. also lacks the fully developed synapomorphic character states of the fossil subfamily Gomphaeschnaoidinae Bechly et al., 2001, it has three characters that can be interpreted as intermediate apomorphic states that suggest a closer relationship with this fossil subfamily, viz. a very oblique (but not yet undulate) pterostigmal brace vein, only a single secondary antenodal crossvein between Ax1 and Ax2 (but not yet aligned), and AX2 shifted basally to the level of the ventral angle (but not yet basal angle) of the triangle (Bechly et al. 2001). We therefore suggest that Elektrogomphaeschna gen. nov. represents the most basal Gomphaeschnaoidinae and the first Paleogene record for this otherwise exclusively Cretaceous taxon, documenting its survival of the K-Pg mass extinction event. Within Gomphaeschnaoidinae the new genus differs from all other genera (except Anomalaeschna and Sinojagoria) in the basal divergence of RP1 and RP2, and the non-undulating smoothly curved and diverging veins RP2 and IR2. It differs from Anomalaeschna Bechly et al., 2001 in RP2 aligned with subnodus, triangles divided and elongate in both wings, and more distinctly braced pterostigmata that span 2-3 cells. It is most similar (and possibly most closely related) to Sinojagoria Bechly et al., 2001 from the Lower Cretaceous of China, but differs in the more elongate hind wing triangle that is only twocelled instead of four-celled.

Fossil Aeshnoptera are known since the Middle Jurassic. This clade was very diverse with numerous extinct families during the Mesozoic (Bechly et al. 2001; Nel et al. 2008, 2015). Nevertheless, the modern clade Aeshnodea has a reduced Mesozoic, Paleocene, and Eocene record, while it is more diverse during the Oligocene and in the Neogene (Bechly et al., 2001; 
Petrulevičius et al. 2010). On the contrary the Gomphaeschnidae were quite diverse in the Cretaceous and the Paleogene, and became successively less diverse in the Neogene. The new fossil genus with two species from Baltic amber confirms the larger diversity and wide geographic distribution of Gomphaeschnidae in the Eocene. Possibly the diversification of the Aeshnodea and especially the Aeshnidae during the Oligocene causes the decrease of the older clade Gomphaeschnidae.

\section{Acknowledgements}

We sincerely thank two referees for their very useful comments on the first version of the paper.

\section{References}

Bechly, G. (1996a) Fossil Odonata in Tertiary amber. Petalura, 2, 19 pp.

Bechly, G. (1996b) Morphologische Untersuchungen am Flügelgeäder der rezenten Libellen und deren Stammgruppenvertreter (Insecta: Pterygota: Odonata), unter besonderer Berücksichtigung der Phylogenetischen Systematik und des Grundplanes der Odonata. Petalura Special Volume 2, 1-402.

Bechly, G. (1998) New fossil damselflies from Baltic amber, with description of a new species, a redescription of Litheuphaea carpenteri Fraser, and a discussion on the phylogeny of Epallagidae (Zygoptera: Caloptera). International Journal of Odonatology 1(1), 33-63. Bechly, G., Nel, A., Martínez-Delclòs, X., Jarzembowski, E.A., Coram, R., Martill, D., Fleck, G., Escuillié, F., Wisshak, M.M. \& Maisch, M. (2001) A revision and phylogenetic study of Mesozoic Aeshnoptera, with description of numerous new taxa (Insecta: Odonata: Anisoptera). Neue Paläontologische Abhandlungen 4, 1-230. 
Bechly, G. \& Wichard, W. (2008) Damselfly and dragonfly nymphs in Eocene Baltic amber (Insecta: Odonata), with aspects of their palaeobiology. Palaeodiversity 1, 37-73 .

Bechly, G. (2016) Phylogenetic systematics of Odonata. - homepage on the Internet: https://dl.dropboxusercontent.com/u/13756162/Website/odonata/system.htm Dijkstra, K.-D.B., Bechly, G. Bybee, S.N., Dow, R.A., Dumont, H.J., Fleck, G., Garrison, R.W., Hämäläinen, M., Kalkman, V.J., Karube, H., May, M.L., Orr, A.G., Paulson, D., Rehn, A.C., Theischinger, G., Trueman, J.W.H., Tol, J.v., von Ellenrieder, N. \& Ware, J. (2013) The classification of dragonflies and damselflies (Odonata). Zootaxa 3703, 36-45.

Ellenrieder, N. von (2002a) A phylogenetic analysis of the extant Aeshnidae (Odonata: Anisoptera). Systematic Entomology 27, 437-467.

Ellenrieder, N. von (2002b) Redescription of Linaeschna polli Martin, 1909 (Anisoptera: Aeshnidae: Gomphaeschninae). Odonatologica 31, 409-413.

Fleck, G., Nel, A., de Plöeg, G. \& Masselot, G. (2000) A fossil dragonfly from the Paris Basin amber of France (Lowermost Eocene) (Insecta, Odonata, Anisoptera). Acta Geologica Hispanica 35, 131-134.

Karube, H. \& Yeh, Wen-Chi (2001) Sarasaeschna gen. nov., with descriptions of female $S$. minuta (Asahina) and male penile structures of Linaeschna (Anisoptera: Aeshnidae). Tombo, Japanese Journal of Entomology 43, 1-8.

Martin, R. (1908-09) Aeschnines. Collections zoologiques du Baron Edm. de Selys Longchamps, Catalogue systématique et descriptif 18 and 19, 1-84, 85-156.

Nel, A. \& Fleck, G. (2014) Dragonflies and damselflies (Insecta: Odonata) from the Late Eocene of the Isle of Wight. Earth and Environmental Science, Transactions of the Royal Society of Edinburgh 104, 283-306. 
Nel, A., Fleck, G., Garcia, G., Gomez, B., Ferchaud, P. \& Valentin, X. (2015) New dragonflies from the lower Cenomanian of France enlighten the timing of the odonatan turnover at the Early - Late Cretaceous boundary. Cretaceous Research 52, 108-117. Nel, A., Martínez-Delclòs, X., Paicheler, J.C. \& Henrotay, M. (1993) Les 'Anisozygoptera' fossiles. Phylogénie et classification (Odonata). Martinia Numéro Hors Série 3, 1-311. Nel, A., Néraudeau, D., Perrichot, V., Girard, V. \& Gomez, B. (2008) A new dragonfly family in the Upper Cretaceous of France (Insecta: Odonata: Aeshnoptera). Acta Palaeontologica Polonica 53, 165-168.

Petrulevičius, J.F., Nel, A. \& Voisin, J.-F. (2010) A new genus and species of darner dragonfly (Aeshnidae: Odonata) from the lower Eocene of Laguna del Hunco, Patagonia, Argentina. Annales de la Société Entomologique de France (N.S.) 46, 271-275.

Riek, E.F. \& Kukalová-Peck, J. (1984) A new interpretation of dragonfly wing venation based upon Early Carboniferous fossils from Argentina (Insecta: Odonatoidea) and basic characters states in pterygote wings. Canadian Journal of Zoology 62, 1150-1166.

Schädel, M. \& Bechly, G. (2016) First Record of Anisoptera (Insecta: Odonata) from midCretaceous Burmese Amber. Zootaxa 4103, 537-549.

Standke, G. (2008) Bitterfelder Bernstein gleich Baltischer Bernstein? - Eine geologische Raum- Zeit- Betrachtung und genetische Schlußfolgerungen. Exkursionsführer und Veröffentlichungen der Deutschen Gesellschaft für Geowissenschaften Hannover 236, 11-33. Wighton, D.C. \& Wilson, M.V.H. (1986) The Gomphaeschninae (Odonata: Aeshnidae): new fossil genus, reconstructed phylogeny, and geographical history. Systematic Entomology 11, $505-522$.

Wolfe, A.P., Tappert, R., Muehlenbachs, K., Boudreau, M., McKellar, R.C., Basinger, J.F. \& Garrett, A. (2009) A new proposal concerning the botanical origin of Baltic amber.

Proceedings of the Royal Society (B) 276, 3403-3412. 
Zhang, Binglan, Ren, Dong \& Pang, Hong (2008) Dragonflies (Insecta: Odonata:

Gomphaeschnidae) from the Yixian Formation in Inner Mongolia, China. Progress in Natural Science 18, 59-64.

Zheng, Daran, Wang, Bo, Jarzembowski, E.A., Chang, Su-Chin \& Nel, A. (2016a)

Burmadysagrioninae, a new subfamily (Odonata: Zygoptera: Dysagrionidae) from mid-

Cretaceous Burmese amber. Cretaceous Research 67, 126-132.

Zheng, Daran, Jarzembowski, E.A., Chang, Su-Chin \& Wang, Bo (2016b) A new true dragonfly (Odonata, Anisoptera, Gomphaeschnaoidini) from mid-Cretaceous Burmese amber. Proceedings of the Geologists' Association 127, 629-632.

Zheng, Daran, Chang, Su-Chin, Jarzembowski, E.A. \& Wang, Bo (2017) The first aeshnoid dragonfly (Odonata: Anisoptera: Telephlebiidae) from mid-Cretaceous Burmese amber.

Cretaceous Research 72, 105-109.

Figure 1. Elektrogomphaeschna peterthieli gen. et sp. nov., holotype SMNS BB-2390. A, drawing of forewing; B, drawing of hind wing (scale bars represent $2 \mathrm{~mm}$ ).

Figure 2. Elektrogomphaeschna peterthieli gen. et sp. nov., holotype SMNS BB-2390. A, photograph of forewing (scale bar represents $2 \mathrm{~mm}$ ); B, photograph of hind wing (scale bar represents $2 \mathrm{~mm}$ ); C, photograph of forewing triangle (scale bar represents $1 \mathrm{~mm}$ ).

Figure 3. Elektrogomphaeschna peterthieli gen. et sp. nov., paratype SMNS BB-2825.

Drawing of forewing and hind wing fragment (scale bar represents $2 \mathrm{~mm}$ ).

Figure 4. Elektrogomphaeschna peterthieli gen. et sp. nov., paratype SMNS BB-2825. A, Photograph of forewing and hind wing fragment); B, photograph of fore- and hind wing triangles (scale bars represent $2 \mathrm{~mm}$ ). 
Figure 5. Elektrogomphaeschna annekeae gen. et sp. nov., holotype MNHN.F.A58663. A, drawing of wing apex; B, drawing of wing base (scale bars represent $3 \mathrm{~mm}$ ).

Figure 6. Elektrogomphaeschna annekeae gen. et sp. nov., holotype MNHN.F.A58663. A, photograph of wing base; B, photograph of bases of RP3/4 and IR2 (scale bars represent 3 $\mathrm{mm})$.

Figure 7. Elektrogomphaeschna annekeae gen. et sp. nov., holotype MNHN.F.A58663. A, photograph of antesubnodal area; B, photograph of nodus (scale bars represent $3 \mathrm{~mm}$ ). Figure 8. Elektrogomphaeschna annekeae gen. et sp. nov., holotype MNHN.F.A58663. A, photograph of mid part of wing; B, photograph of wing apex (scale bars represent $3 \mathrm{~mm}$ ). 


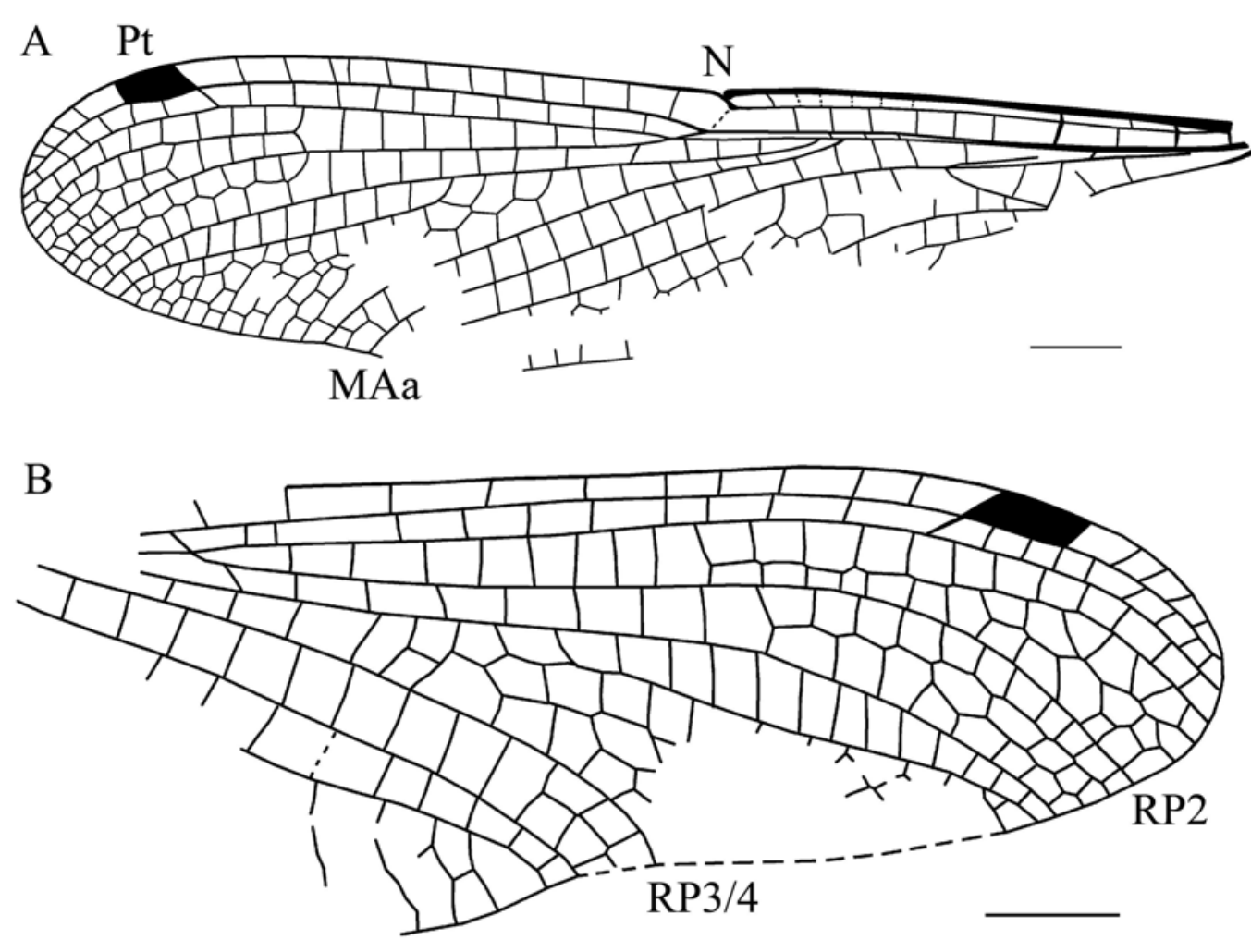



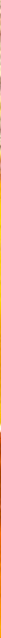

18

$\sqrt{1}+3 \times \frac{39}{4}$

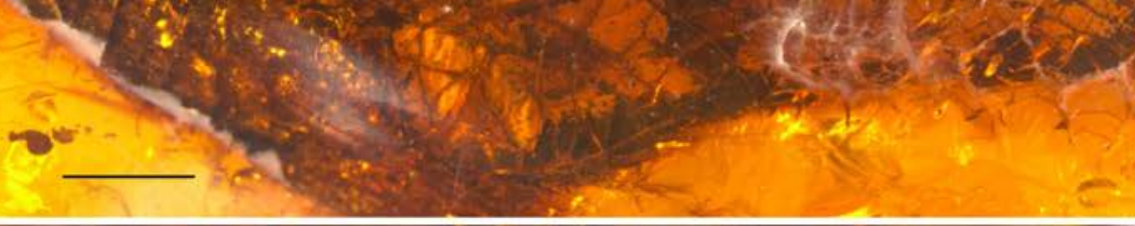

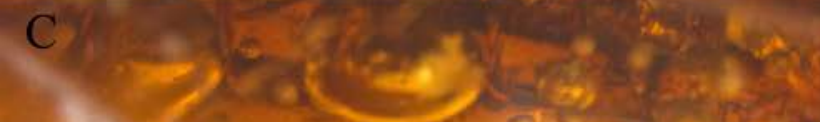

$10710+45625$

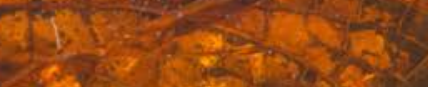

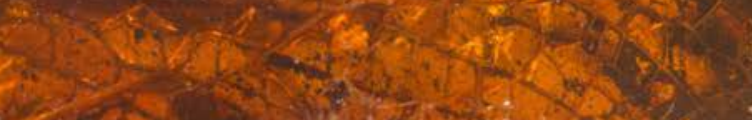
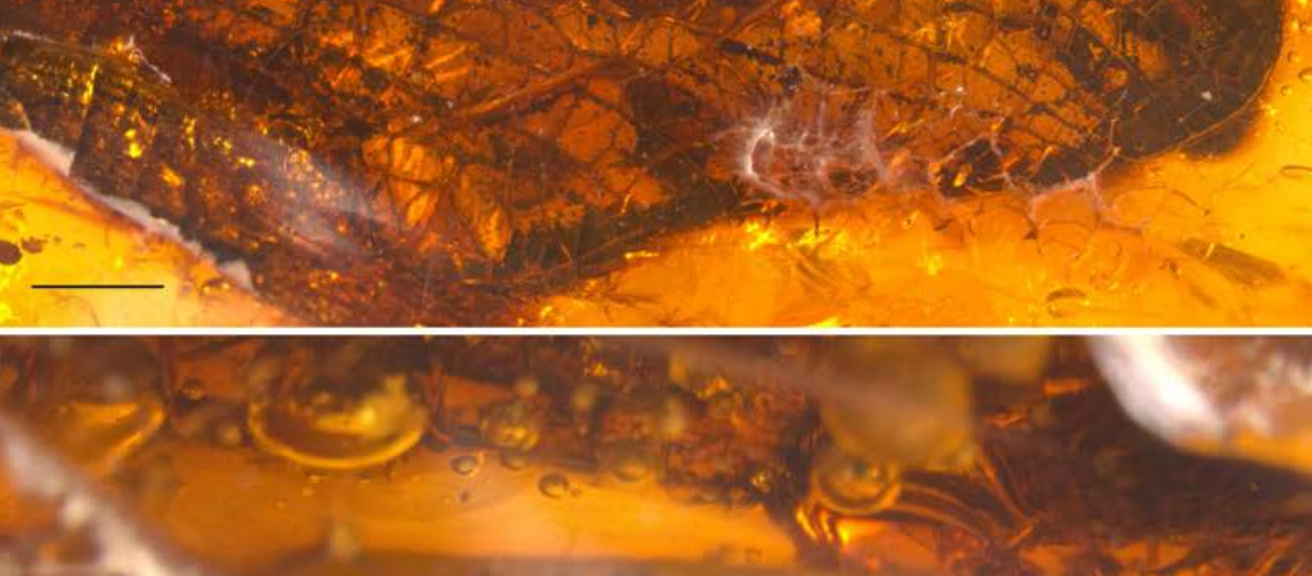

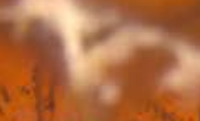

$\frac{5}{6}$

Nat

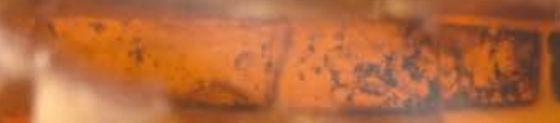

se.
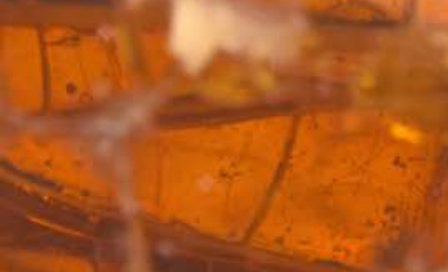

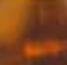

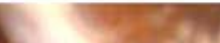

तो

2
4

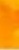




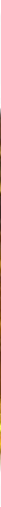




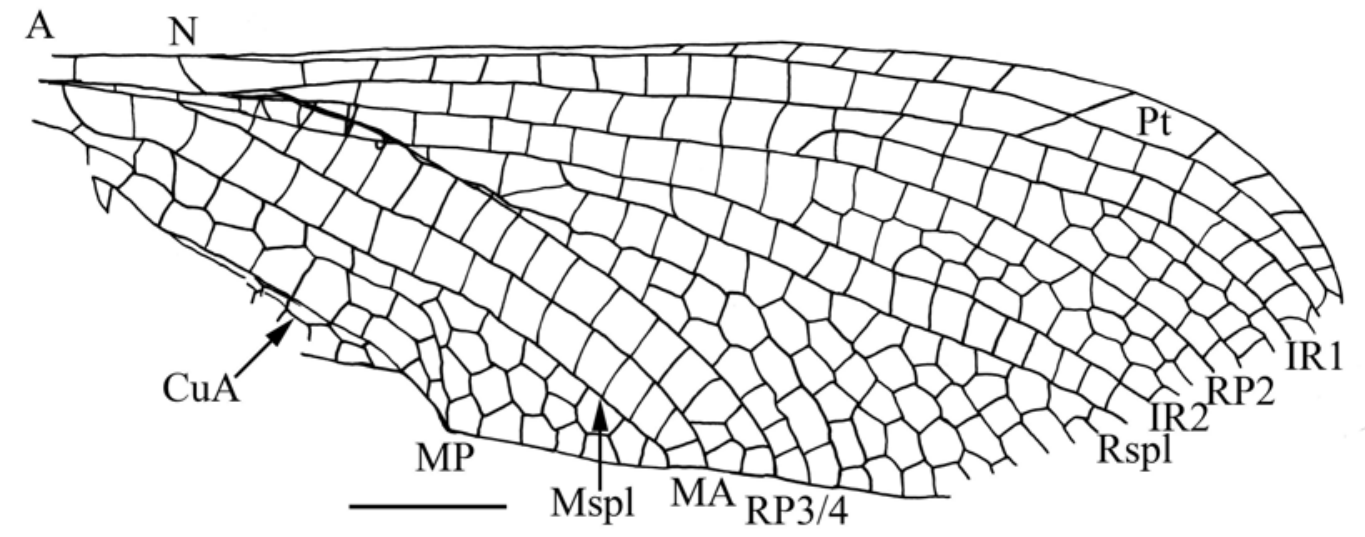

B

basal side

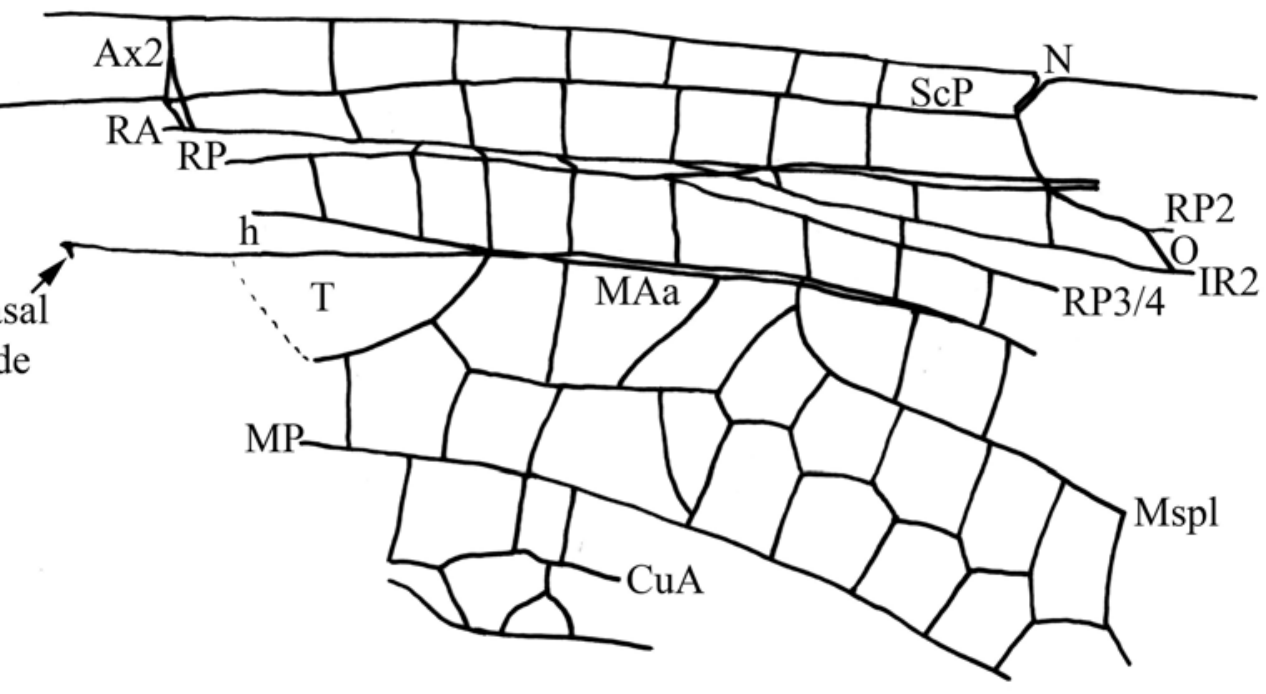




\section{A}
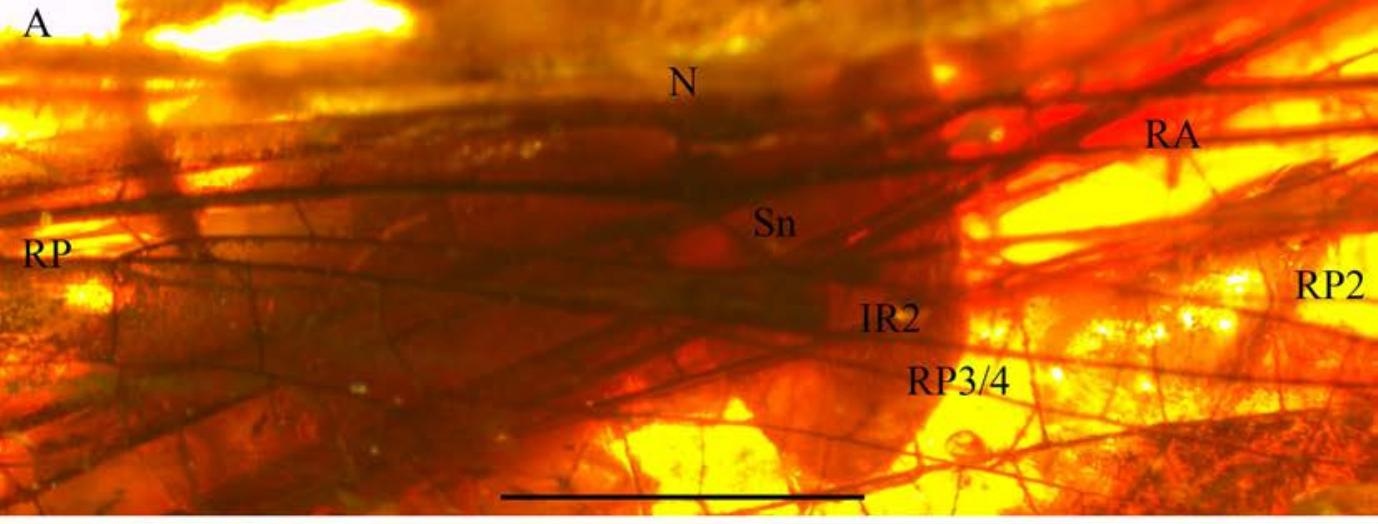

\section{B}

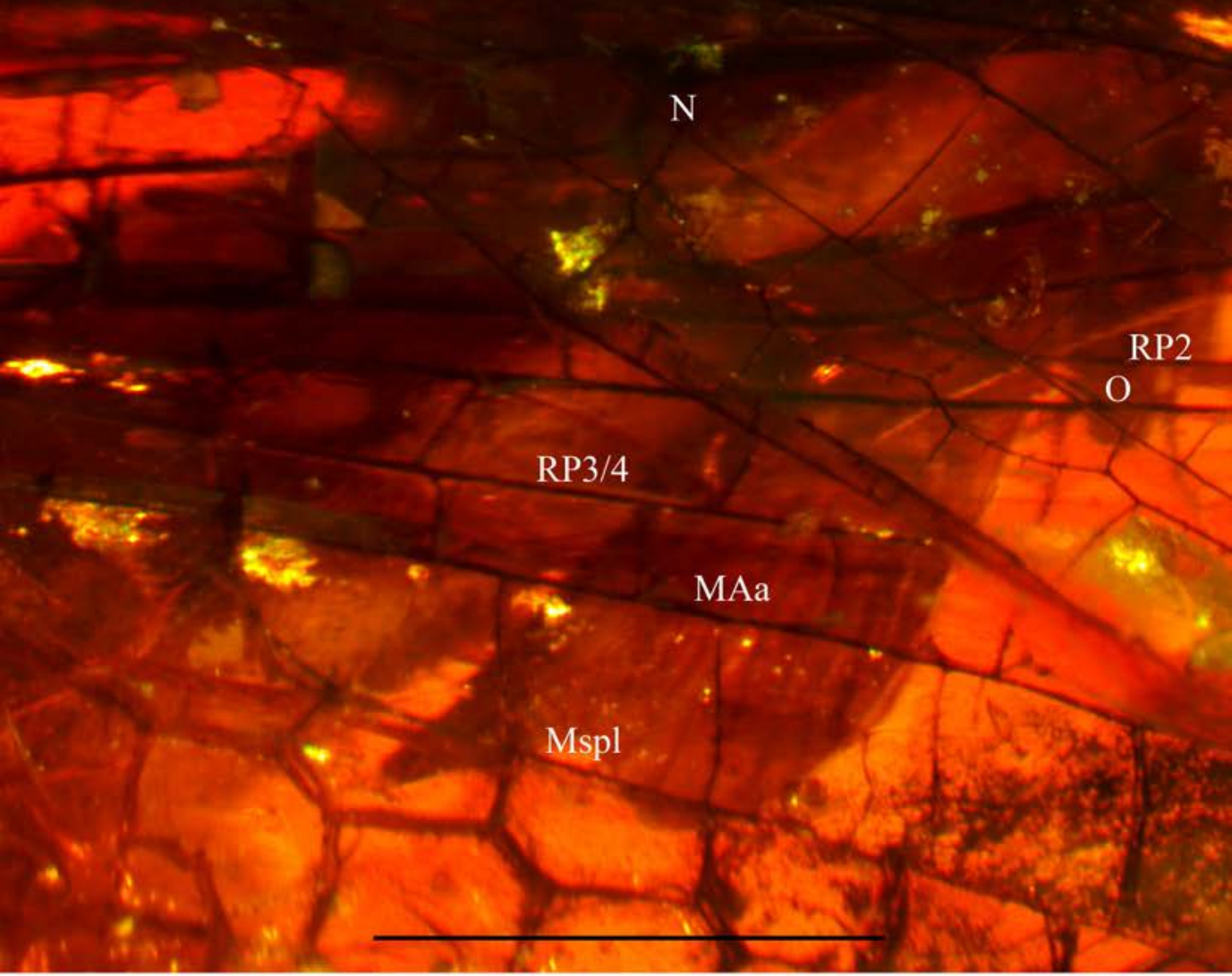




\section{A $\quad+3 \times$.}
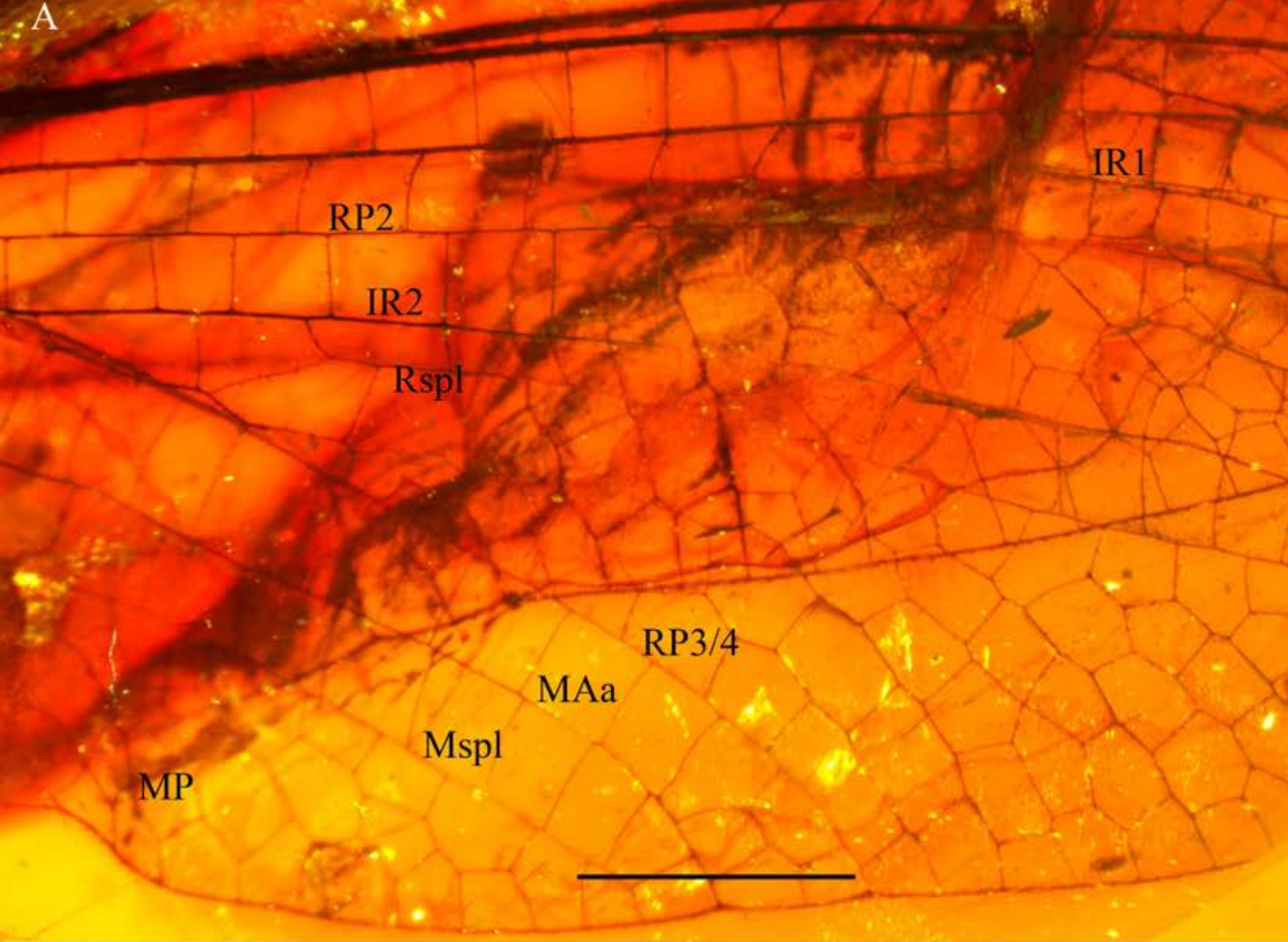

\section{B}

$-8$

、

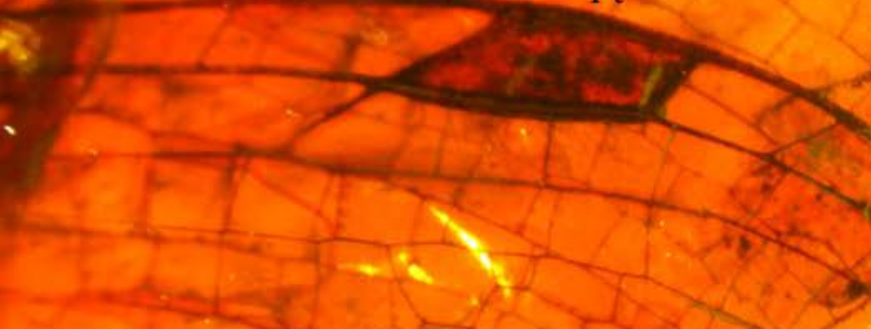

4

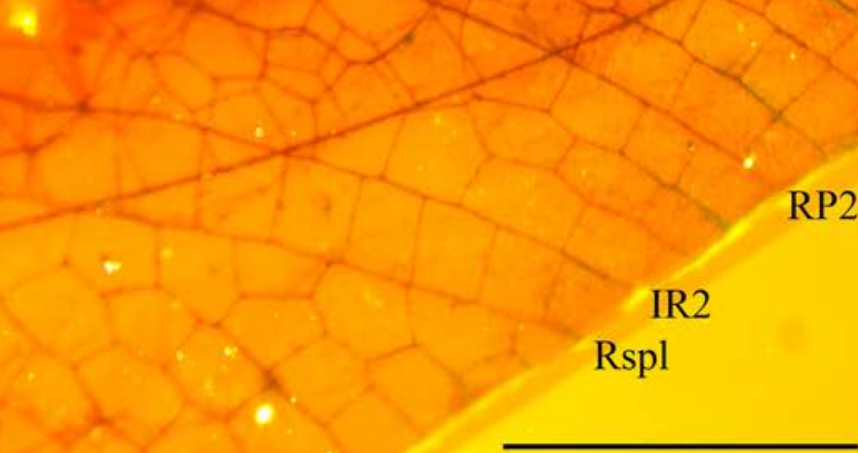

